\title{
AN EXPLORATION OF POTENTIAL REWARDS IN ENGLISH FOR YOUNG LEARNER (EYL) CLASSROOM
}

\author{
Indra Yoga Prawiro ${ }^{* 1}$, Natalia Anggrarini ${ }^{* 2}$ \\ yogaprawiro@gmail.com ${ }^{* 1}$, natalia.anggrarini@unwir.ac.id ${ }^{* 2}$ \\ Faculty of Teachers Training and Education Science - English Education Department \\ University of Wiralodra
}

\begin{abstract}
ABSTARCT
In the $21^{\text {st }}$ century, many parents try to introduce foreign language since earlier. The introduction is started since very beginning because some experts believed that the students who learn foreign language especially English on their primary schools or preschools, it will contribute the successful of them in learning language in the next level Ferrandino and Tirozzi as cited in MacDonell, C. (2007:1). This research is a case study. It aims to find out the use of potential rewards in kindergarten schools. This study will also investigate some challenges and efforts of five EYL teachers in teaching English. Hence this study will also focus on the benefits of potential rewards in motivating the EYL students in learning English. The result showed that social reinforcers is the most used reward and three activities that usually implemented in the class are giving applause, smiles and teacher's signature. Then, there are two main challenges in teaching English in kindergarten school. The first is the use of technology and the second is classroom management. While the efforts used in teaching EYL are the use of media, strategy and rewards. So, the students will be more fun and enjoyable in learning English. Then, the last is the benefits. The result showed that by implementing the rewards system in the class. It can encourage the students to achieve the target learning. The students are happy to follow the instructions from the teacher and can complete the task well.
\end{abstract}

Keywords: Challenges, Efforts, English for Young Learner, Potential Rewards, Teachers' Experience.

\section{INTRODUCTION}

In the $21^{\text {st }}$ century, many parents try to introduce foreign language since earlier. The introduction is started since very beginning because some experts believed that the students who learn foreign language especially English on their primary schools or pre-schools, it will contribute the successful of them in learning language in the next level,Ferrandino and Tirozzi as cited in MacDonell, C. (2007:1). Some of the countries offer these programs in primary schools while others introducing these programs starting from kindergartens,Puskas, A. (2016:10). These trends are increasing day by day throughout both English language program at school and courses, Edwards, A \& Knight, P (2001).

However, introducing English language programs are still debatable.Some researchers have been shown the benefits on introducing English language programs for Young learner. Paradis (2004), McKay, P. (2006) and Johnstone (2009) believed that when the children learn English earlier, they can acquire the second language naturally. Furthermore, some researchers also believed the use of rewards will support the learner in learning English. Whereas others believed in 


\section{Indra Yoga Prawiro ${ }^{* 1}$, Natalia Anggrarini ${ }^{* 2}$ \\ AN EXPLORATION OF POTENTIAL REWARDS IN ENGLISH FOR YOUNG \\ LEARNER (EYL) CLASSROOM}

giving punishment will also give influence on the process, Watson as cited in Kail, V. R. (2012).

The uses of reward and punishment in learning English Language have also been implemented in many countries. The first study is reported by Khaliq, A., et al. (2016). The study focuses on the role of reinforcement or punishment in learning English language in Pakistan. The study showed that teacher can enhance the learning process by using reinforcement or applying punishment tool. The second study is presented by Langa, C. (2014). The purpose of the study is to identify the most efficient modalities of intervening on the child's disturbing behavior applying the punishment-reward duet in Rumania. The results show that offering rewards in a correct and fair manner makes the pupil to be an aware accomplice to the educative act. The last study is implemented in Vietnam by Loi, D. P. \&Uyen, N. T. L. (2016). This study focuses on the use of reward to increase students' motivation and participation in learning English language. The study found that the success of a rewarding system may be affected by different classroom activities. Compared to those studies that focus on the use of rewards and punishment in intermediate level and secondary schools, this study focuses on the use of potential rewards in kindergarten school. This study will also investigate some challenges and effort of EYL teachers in teaching English in Kindergarten School. Hence this study will also focus on the benefits of potential rewards in motivating the EYL students in learning English.

\section{LITERATURE REVIEW}

\section{Teaching English for Young Learner}

More than decades many experts especially psycholinguist have discussed about the way of children in learning a language. The psycholinguist was investigated on how the children acquire their first language. They also have started to investigate how the children get their second language. However, the result was really surprising. Some of them claimed that there are many similarities on how the children get their first and second language. While others believed that there are no differences between the way of children getting their first and second language. Therefore, it can be concluded that people cannot separate the learning process of children in acquiring their first and second language because it has many similarities, Gordon, T. (2007).Pinter, A. (2011) has divided young learners into three groups. The first is children who start pre-school at about the age of three, the second is the group of children who start primary school at around the age of 5-7 and finish primary school 11 or 12, although in some countries it happens at around the age of 13 or 14 .

\section{The Foundation Theories of Children Development}

John Watson (1878-1958) as cited in Kail, R. V. (2012) was the first theorist that focused on the children development. According to his perspective, He believed that learning process really influenced the future of the children. Then he also argues that experiences established the process of development. Other theorist, Jean Piaget (1896-1980) as cited in Kail, R. V. (2012) argues that children have a sense to set up their own world. The children learn throughout 
infancy, childhood, and adolescence, youngsters want to understand the workings of both the physical and the social world.

\section{The Benefits of Early Language Learning}

Young learners have a variety of skills and characteristic features that help them to learn a foreign language. Halliwell, S. (1992) underlined several qualities of young learners that considers really beneficial for language learning. She claims that children easily understand the new sentences in native language without knowing the meaning of every single word. Then, the children can also explore their minimum language in an attractive way. Thus, the children can also learn without any structured method. Sometimes, the children learn the native language unconsciously from their daily activities such as watching a cartoon movie or listen to the music, Paul, D (2003). Then, the students also tend to learn something that enjoyable. The students have their own imagination. So, it will also help them to acquire their second language. The last, the children known that they have no much anxiety in making a mistakes while talking to others. Therefore, it can make the children easily to learn and accept something new on the acquisition process. The statements above are also supported by other researcher. Johnstone, R. (2009) stated that children have a good skill to learn language than older learner. The children have no intention to feel guilty when they make a mistake.

\section{Potential Classroom Rewards}

Reinforcement is a one of the way used by teacher to lift students' skill. There are two kinds of reinforcement. The first is positive reinforcement and the second is negative reinforcement. Positive reinforcement can be applied by giving some gifts. For example after getting a highest score in the class, the teacher announces it in front of the class. While negative reinforcement is rewarding the people by taking away unpleasant things. For example, the one who get the highest score do not need to clean the classroom for a week, Kail, R. V. (2012:11).

Partin, R. L. (2009) stated there are six types of potential rewards that can be used for the teacher to encourage the students to achieve the target learning. The first is tangible (physical) reinforcers. The examples of tangible (physical) reinforcers are cookies, books, stickers, candy, gift certificates, crayons, pencils, chocolate, plaques, and fruit. The second is activity reinforcers. For examples: choose seats, breaks, recess, receive "no homework" pass, be first in line, watch movies or videos, display work, take pictures, play musical instrument, watch TV, extra locker space. The third is Help the Teachers. For examples: construct bulletin boards, collect papers, be line leader, tutor other students, take attendance, help with experiments, arrange furniture, use the computer, take pictures or movies. The next is rental privileges. The examples are games, hand puppets, laptop computer, table toys sports and playground equipment, books, CDs, DVDs, magazines, colored pencils. Number five is Social Reinforcers. For examples: grades, applause, smiles, nods, hugs, drawings on papers, smiley faces, stickers, awards, check marks, positive comments on papers, teacher's signature, compliments. The last is Recognition. The examples are name 
mentioned in assembly, student of the week, letter to parents, work displayed, phone call to parents, photograph in paper, name in paper, trophies, stars, honor roll, photograph on bulletin board.

\section{RESEARCH METHODOLOGY}

It is previously mentioned that the study aimed to investigate the potential rewards given to young learners who learn English in the class. This study will also describe the challenges of EYL teachers in teaching young learners and capture the used of rewards in motivating students to learn English. According to Cresswell, J. W. (2009) qualitative research has a purpose to explore and understand the individual or group ascribe to a social or human problem. In this study, the writer will use descriptive qualitative research that is case study, as the research design to explore and describes the issue based on the individual perspectives.

\section{FINDINGS AND DISCUSSIONS}

\section{The Kinds of Potential Rewards Used to Motivate the English Young Learner in the Class}

Children have their own perspective that will be different from one to another especially in language learning. Therefore, it needs support from the teacher to create an interesting classroom because the children are known easily to get bored. To makes the children not bored, the teachers should do reinforcement that can give motivation to students. One of the reinforcement is reward. Reward can be used by teachers to motivate young learners in learning. In this research, five teachers was given questionnaire by the researchersabout the kinds of potential rewards used by teachers in teaching English to young learners students. The result shown in the table below:

Table. 1

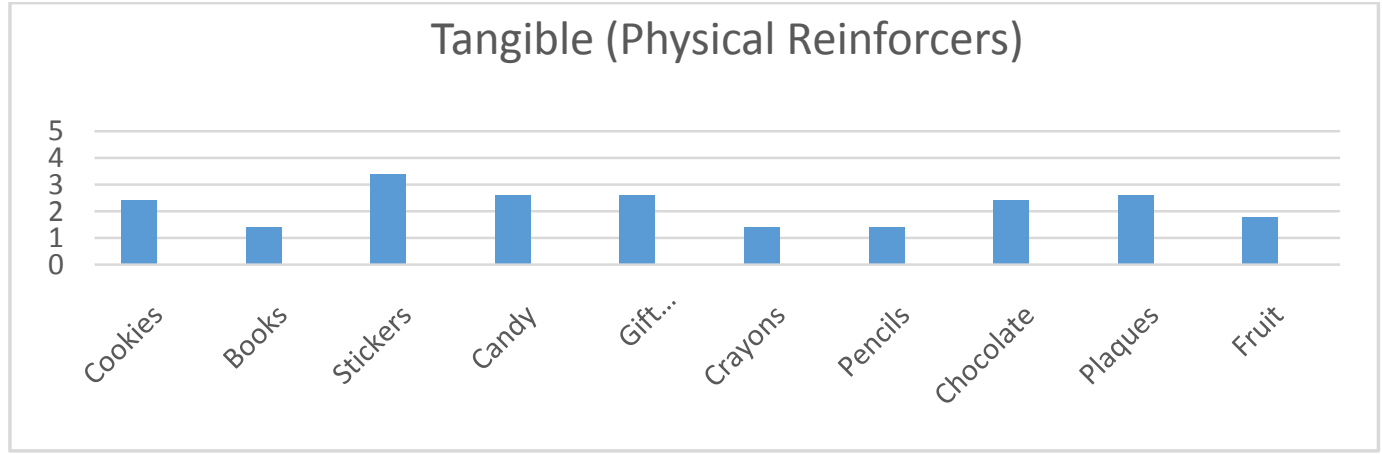

Based on the table 1 above, the information provides degrees of giving potential reward to young learners by using tangible reinforcers or physical reinforcers. The data shows that there are four most used tangible reward. The first refers to the stickers with the mean 3,4. Put the stickers on their works is really fun for the young learners. They can show it not only to their friends but also to their parents. Therefore this reward is often used by teachers as a reinforcement for the students that they have done the task and for the parents it can be a sign if their children can follow the class well. Then, it is followed by Candy, Certificates and Plaques with the similar mean 2,6. However, the use of 
tangible (physical) reinforcers is still low. The data taken from 5 teachers show that the mean of tangible reinforcers is only 2,2 .

Table 2

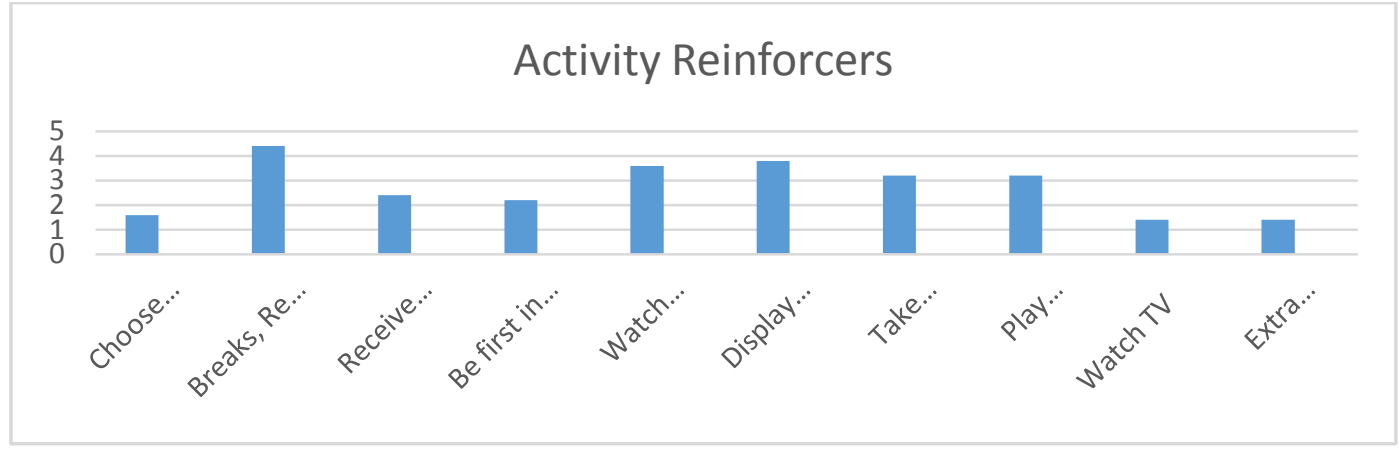

The table 2 shows there are ten activities which becomes reward as the appreciation for students based on the questionnaire. Then, there are three major potential rewards chosen by 5 teachers. The first is breaks or recess. It is interesting for the students because when the students have completed the task well. They are allowed to have a break, to do everything they want such as playing outside the class or eat. The second is display work. Then, the third potential reward is watch a movie or video.

Table 3

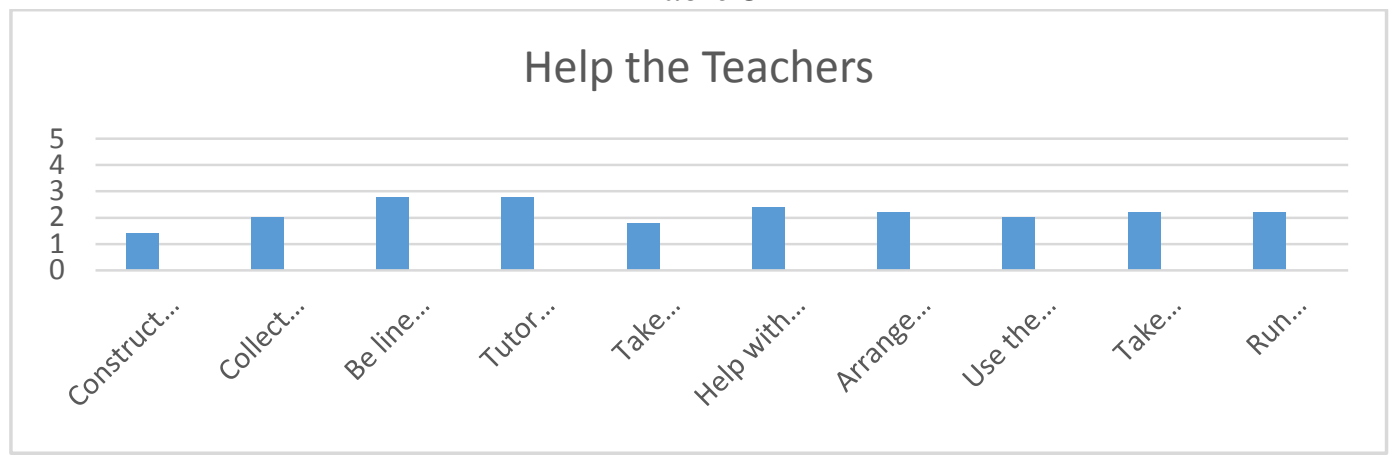

Then the third potential reward is helping the teacher. Similar with tangible reinforcers, helping the teacher is also not really familiar for the teacher. From ten activities, there are only two activities that commonly implemented in the classroom. The first is be a line leader with the mean 2,8 . Be a line leader is really challenging for the students. Because it shows their responsibility as a captain of their friends. Then the second is Tutor other students with the mean 2,8. 
Table 4

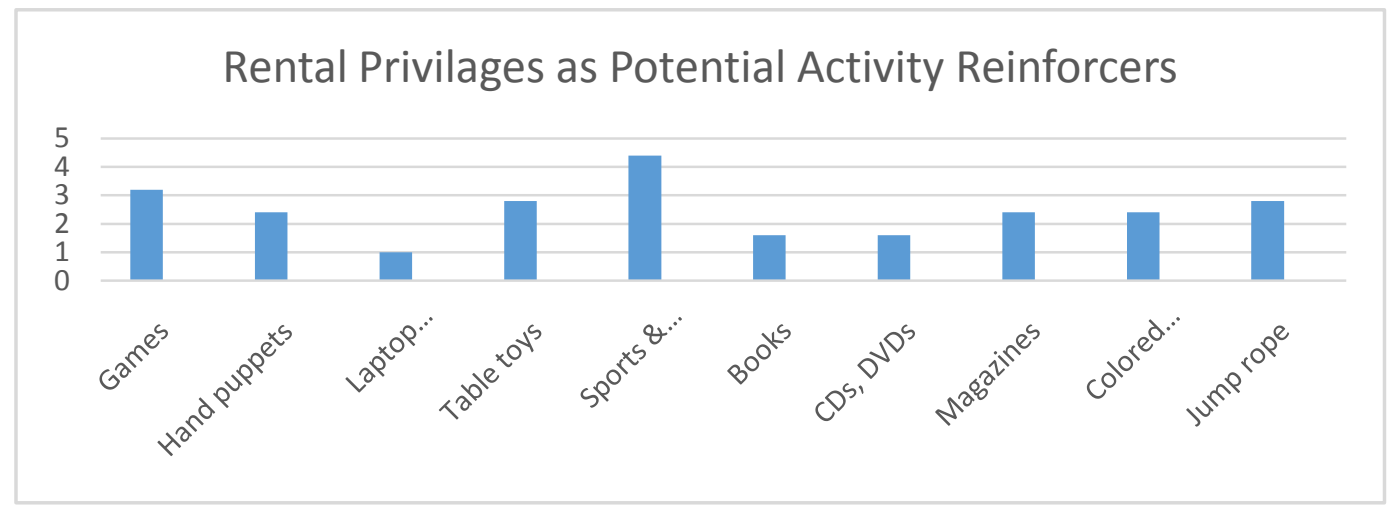

The table 4 shows the use of rental privileges reinforcers as potential reward to young learners in class. According to the data above, the most rental privileges reinforcers is doing sport and use playground equipment. This activity is really useful for the students to discharge their energy. The mean of this activity is 4,4 . It shows that most of the teachers used it as the rewards for their students. The second activity as a reward is games with the mean 3,2 . In the third position, there are jump rope and table toys used as a reward. It has a mean 2,8 .

Table 5

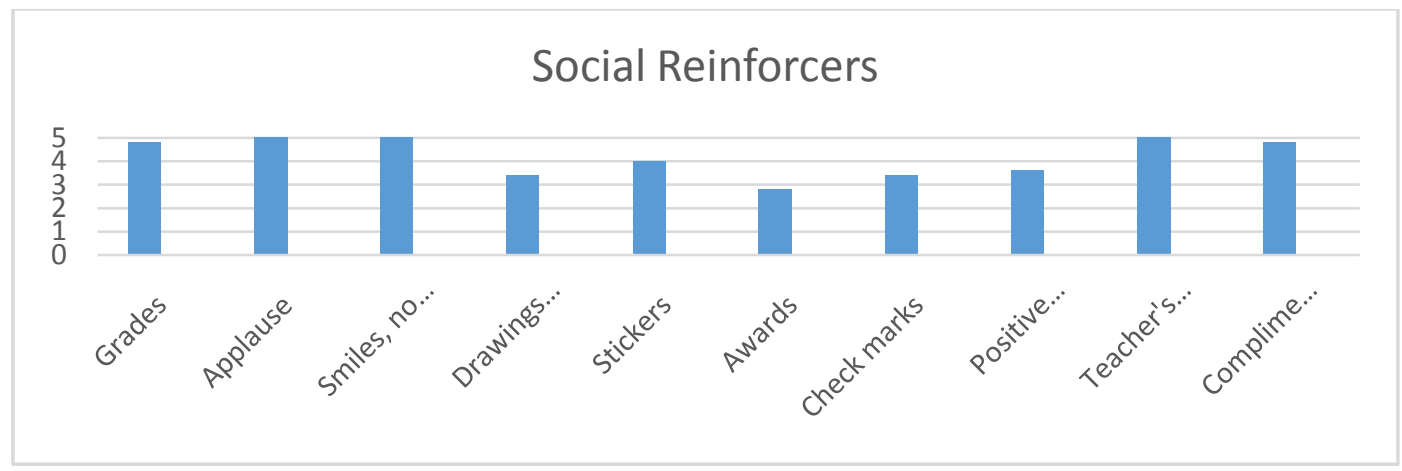

The graphic shows the use of social reinforcers as potential reward in teaching young learners. Based on the data, most of teachers always give social reinforcers to students. It can be seen through the information which is shown from the table that showed five teachers always give applause, smiles, nods, hugs, and teachers' signature as potential reward to young learners. This makes the social reinforcers as the most kinds of potential reward used by teachers. Without spend any cost, social reinforcers can be useful to express and praise the students' works.

Then the last potential rewards is recognition, the table 6 shows the use of recognition in TEYL classroom. 
Table 6

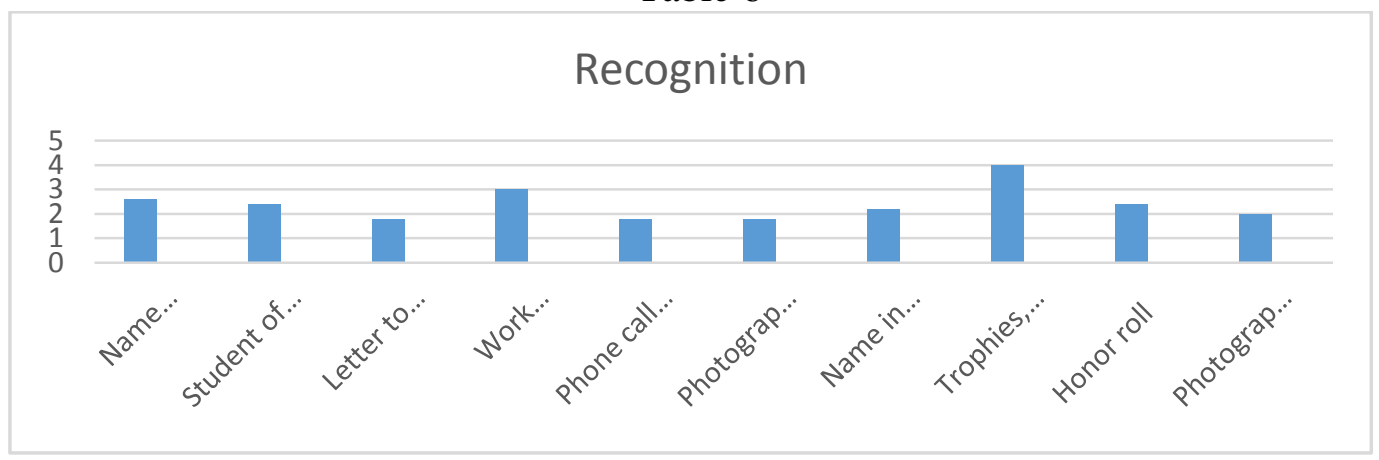

The result shows that most of the teacher uses stars or trophies as a rewards to their students. The mean 4,0 shows that most of them aware with the progress of their students. Therefore the teachers give it as a motivation for them. Then the second is work display with the mean 3,0 .

\section{The Challenges Found by the Teachers in Teaching English Young Learner in the $21^{\text {st }}$ Century Era}

One of the way to introduce English Language is by using technology such as internet, YouTube and learning applications. However not all teachers are familiar with the technology especially for those who have been teaching for about 20 years. In the interview session the $1^{\text {st }}$ teacher stated that

Oh ya the challenge perhaps refers to the condition when the children know more than me. In this case, they have known the song and sang it in the class. Then I ask them about the title and search it in YouTube at home, so the next day I can ask them to join singing together at class. So I am able to know the song from my students.

Considering this situation, $1^{\text {st }}$ teacher faces the challenge to access more on YouTube. Some teachers have a challenge to deal with the use of internet on their teaching. Because for a long time ago, many teachers only concern with the use of the book to teach their students. However in the $21^{\text {st }}$ century, the teachers cannot keep the distance from the use of technology. So, the teacher has to follow their students' habit to give a new experience for their students. This statement is supported by John Watson (1878-1958) as cited in Kail, R. V. (2012) who stated that learning process really influenced the future of the children. Then he also argues that experiences established the process of development.

The other respond which brings the technology in term of the using of gadget as the challenge is stated by $2^{\text {nd }}$ teacher who stated that students often know more information than the teacher. From the interview session the $2^{\text {nd }}$ teacher stated that

The challenge is making them understand what I mean, however sometimes they know all of thing related technology than me.

According to the statement of $2^{\text {nd }}$ teacher, it can be concluded that the development of technology nowadays is unstoppable. The children are easily to 


\section{Indra Yoga Prawiro ${ }^{* 1}$, Natalia Anggrarini ${ }^{* 2}$ \\ AN EXPLORATION OF POTENTIAL REWARDS IN ENGLISH FOR YOUNG \\ LEARNER (EYL) CLASSROOM}

access everything that they want. Because now days the parents also facilitate their children with the gadget and internet hotspot at home. So, it is not surprising that children have known first than their teacher. This statement is supported by Paul, D (2003) who stated that the children learn the native language unconsciously from their daily activities such as watching a cartoon movie or listen to the music.

The other challenges of teaching English for Young Learner faced by $3^{\text {rd }}$ teacher is a little bit different than two teachers before. The $3^{\text {rd }}$ teacher acknowledged that challenge in teaching English for Young Learner refers to classroom management. The $3^{\text {rd }}$ teacher stated that

Actually it is so challenging in the first time and there is a big difference because at that time I also taught at university, so the comparison between college students and kindergarten students is really huge like a ground and sky. In this case, it is so easy to deal with college students by saying look out, but different condition must happen with kindergarten students. We must move, I mean the using of words is not enough to control them.

Based on the $3^{\text {rd }}$ teacher perspective, it can be concluded that each student has its own character because each of them has different wants and needs. This statement is in line with Jean Piaget (1896-1980) as cited in Kail, R. V. (2012) who argued that children have a sense to set up their own world. Therefore, the teacher needs to learn each student character so it will help the teacher in in managing the classroom.

The same perspective is also stated by the $4^{\text {th }}$ teacher which puts classroom management as the challenge in teaching English for Young Learner. It is explained that the classroom provides unpredictable circumstance which requires teacher to be ready in each occasion. The $4^{\text {th }}$ teacher stated that

It is sure that teaching the Kindergarten students is difficult thing. There are the noisy students, and there are the students who fight each other. The students must be like that. My difficulty is how to manage that problem. Students' character are different each other. There are very naughty students, and kind students.

The $4^{\text {th }}$ teacher specifies that real action is really needed to manage the classroom. In this case, teacher does the improvement to children in term of creating the close relation between students and teacher. For instance, the $4^{\text {th }}$ teacher delivers question to students who are crying personally and it is hoped that students are able to open their voice, thus teacher may recognize what students' need.

Following that, the $5^{\text {th }}$ teacher explained that extra patience is necessary to face children. In this case, children usually has set their own world as stated by Jean Piaget (1896-1980) in Kail, R. V. (2012). This condition also happens on the $5^{\text {th }}$ teacher's students which are revealed when it is very often for children to change one topic to another in talking. Considering this condition, the learning process faces unpredictable moments which requires teacher to be active and 
patient in handling the classroom. As stated by the $5^{\text {th }}$ teacher in the interview season, she stated that

The challenge refers to the extra patience that must be had by teacher. It is because basically children often change the topic when they are given an explanation.

\section{The Effort Used by English Young Learner Teachers in Motivating the Students to Learn English}

The $1^{\text {st }}$ teacher realizes the necessary of build interactive learning process to motivate students in learning English. The learning process here is expected to provide the curiosity among students which guides them to learn more about English. It is revealed through the interview, the $1^{\text {st }}$ teacher stated that

It is because English doesn't become main subject, so it is not learnt deeply actually. We only learn the basic one such as color, things around class and so on. So I motivate my students by giving them opportunity to guess. For example, when we learn about color in English, I ask to class, 'apayabahasaInggrisnyawarnamerah?' and they will answer 'red'. Then it is necessary for us to bring the learning media and give the compliments to students, so it will motivate them.

The $1^{\text {st }}$ teacherstatedthat the learning material at that school is not too hard. The students only learn something that they meet in their daily life such as color and things around the class. However these light materials encourage teacher to provide enjoyable learning process by providing students opportunity to guess or involve in riddle. Then, the $2^{\text {nd }}$ teacher utilizes the using of media in term of YouTube such as animation video to support students in achieving the goal of learning. The using of media increases the attention of students in learning process, thus the material understanding is reached effectively. This statement is revealed through the interview below.

Usually I give them sticker, and then introduce the material by media. Actually, they can, they understand, but because I am not English teacher I just do my best as much as I can give in teaching.

The $2^{\text {nd }}$ teacher gives the sticker for the students who involve into learning activity well such as doing the assignment. The presence of sticker here belongs to positive reinforcement because it is applied by giving some gifts as said by Kail, R. V. (2012:11). Then it is specified by Partin, R. L. (2009) who mentions that sticker is one of tangible (physical) reinforcers. This sticker encourages students not only to enjoy learning but also do the best. So, they will get the appreciation from their teacher.

Then, Based on the $3^{\text {rd }}$ teacher explanation, students get motivation in learning English by receiving compliments. As stated by the $3^{\text {rd }}$ teacher on interview below. 
Yes, we give more compliments for them. Then the nomination of best student also gives the influence because the students feel proud when they are given reward in front of people. They always say I want to be best student, miss. Then I motivate them to study well by involving the rule and so on.

Based on the interview above, the $3^{\text {rd }}$ teacher gives appreciation to students by giving them activity reinforcers which is conducted by choosing the best student as stated by Partin, R. L. (2009). The chosen of best student here challenges students to prove the best intention in learning English. Therefore the goal of learning will be easily achieved.

Furthermore, children are interested to do something when they like that activity. It is confirmed by $4^{\text {th }}$ teacher who acknowledged that her students are really enjoyable in learning English especially when they get the rewards. In this case, the students are given physical rewards such as jelly and cake. It is known through the interview below.

I remember at that time I taught students about alphabet and number. Then I gave students the jelly when they could practice well and then students were happy, even it is only a little jelly. It is because they belong to special students who get the jelly, when the other students do not. However the other rewards is also given to support learning process such as applause. So the students are motivated to study English.

According to the interview above, the students receive two kind of rewards which is mentioned by Partin, R. L. (2009) that refers to physical and social reinforcers. Physical reinforce here usually influences the students individually. While the social reinforcers will influences others to get the same thing.

The others effort of teacher in teaching English for Young Learner comes from $5^{\text {th }}$ teacher who has intention to build imagination among students by using the experience. She stated that

Actually I share my personal experiences when I was on elementary and junior high school so that the students are able to get influence in loving English. However sometimes students do not get too serious about the stories that I share and I do not know which part that is noticed by them.

The $5^{\text {th }}$ teacher uses her experience and story in providing students media to develop their imagination and then it is able to influence students curiosity. It means that when students are curious enough to the story, teacher is easier to guide students in learning English. 


\section{The Benefits of Potential Rewards in Influencing English Young Learner in Learning English}

As mentioned by Partin (2009) that one of the benefits in giving the rewards is to encourage students in achieving the target learning. It means that it is really beneficial for the teacher to use potential reward in creating the good classroom management, thus the goal of learning is able to reach. From the interview, the $1^{\text {st }}$ teacher explained the benefit from potential rewards,

Of course. They are proud what they have done during learning which is written at their book report. It is shown when they tell their parents when they get the stars because of the good achievement in learning activity.

Based on the first teacher's statement, it can be concluded that young learners are more confidence and proud in learning English when they get the rewards. It means that most of the young learners put their high attention towards the reward which they get. Therefore, they share their happiness by showing it to their parents. The young learners here have willingness to get their parents' attention and show how proud they are when they are better than the others. In the other side the potential reward here influences the other students who do not get the reward to study better than before. It is because they are encouraged to improve. The $2^{\text {nd }}$ teacher in the interview session stated that

Usually I give them sticker, and then introduce the material by media. Actually, they can, they understand, but because I am not English teacher I just do my best as much as I can give in teaching. Then I often use sticker and star stamp. Moreover I also say "good job" for them.

It can be concluded that the use of potential reward guides young learners to understand more related to what they have learnt. In this case, teacher gives rewards to students who are able to define the teacher's instruction in term of question, activity, assignment etc. When there is student who get reward, the others will recognize what should they do to get that reward and at the same time they will realize the goal of learning.

The use of potential reward is also acknowledged by the 3rd teacher who uses one of social reinforcers in term of compliment and recognition as mentioned by Partin, R. L. (2009). In this case, the $3^{\text {rd }}$ teacher decides the category of best student to develop students' effort in learning English because there is certain proud shown by students in front of others. This statement is delivered through the interview below.

Yes, we give more compliments for them. Then the nomination of best student also gives the influence because the students feel proud when they are given reward in front of people. They always say I want to be best student, miss. Then I motivate them to study well by involving the rule and so on. 


\section{Indra Yoga Prawiro ${ }^{* 1}$, Natalia Anggrarini ${ }^{* 2}$ \\ AN EXPLORATION OF POTENTIAL REWARDS IN ENGLISH FOR YOUNG \\ LEARNER (EYL) CLASSROOM}

From the statement of the $3^{\text {rd }}$ teacher above, it is concluded that the young learners feel very proud when they get reward in front of others. Because the young learners feel that they are the best among the other students.

Then the $4^{\text {th }}$ teacher stated that the use of potential reward is able to influence the outcome which causes students' achievement improved. It means that the potential reward here is expanded not only giving the benefit on the process of learning but also the end of learning or in this case refers to outcome. It is revealed through the statement of the $4^{\text {th }}$ teacher's interview below.

The students recognize new vocabularies. So when their parents ask them to practice using that vocabularies, the students are able to do that. In this case, they are successful to practice because of the influence of reward which guides them for having curiosity in learning English. However actually if we teach English every day, they will get more understanding and considering this condition, the learning process of English which is taught once a week should be enjoyable through the using of reward itself.

Then the $4^{\text {th }}$ teachers admits that the use of reward influence the performance of young learners which is not just in the classroom, but also outside the classroom.

The $5^{\text {th }}$ teacher explained another benefit on the use of potential reward. The $5^{\text {th }}$ teacher uses reward to persuade the students to be diligent in learning. It is known through the interview below.

I give the reward for students who study hard. For instance, students who are good at coloring. Furthermore I also give reward for students who do not come to the class because they are sick. In this case, I try to serve reward as their spirit in doing something especially in learning.

Based on the interview, it brings the fact that the $5^{\text {th }}$ teacher gives reward to the students that have successfully completed their works. Because it shows that the students are good enough in following the instruction of their teacher.

\section{CONCLUSION}

Teaching English for young learner will creates different experience for teacher. Because the children have their own behavior and characteristic that prefer to enjoy the thing which can attract them. There are various kinds of rewards used by teacher in this study. In this case, the social reinforcement become the most used reward among the students. Because it does not take any cost and hard preparation. Furthermore social reinforcers can be useful to express and praise the students' work which is more intimate for the relationship between the students and the teachers or students to students. The kinds of social reinforce here belong to applause, smiles, nods, hugs, and teachers signature. However the variety of reward is able to serve more enthusiasm of students. This study expands that the tangible rewards in term of sticker is also used very often by teacher to appreciate students' works. In this study, students can be motivated through sticker because it is the real thing which gives students the confidence to compete 
to get the sticker. Based on the finding above, the teachers use potential reward in the classroom to create good atmosphere for students, thus the students are able to enjoy the learning process. Even each teacher has different kind of reinforcers. But, they have similarity in reaching the benefits from potential rewards in the classroom.

Then, there are some challenges which found in this study based on the five teachers' information. The first challenge refers to the use of technology. There are some media that really familiar with the students' second acquisitions. One of them is YouTube. From the YouTube the students can learn many things. However, not all the teachers are familiar with this technology. Because, when the teacher uses YouTube as the media in learning activity, it can provide enjoyable learning process for students. Because it provides various attractive content that is fun and useful. The second challenge refers to the classroom management which requires the teacher to recognize the different characters and needs of students. In this study, it is revealed that the real action is really needed to manage the classroom. It means that teacher must create the close relationship to make the students comfortable in learning Native language.

Then, in teaching English for young learner requires the teachers to do more efforts. Building good atmosphere in classroom condition for students is necessary to involve them in learning activity. And then the key to drive it effectively depends on teacher's strategy whether they can accommodate students' interest or they find difficulty to keep the focus of students in learning process. This study reveals various efforts of teachers in giving some rewards for students in learning English.

Furthermore, this study showed some benefits toward the use of potential rewards.The first, the students feel respected which guides them to study more and involve into learning activity thoroughly. This situation then encourage students to develop their willingness in participating on each learning process. The second benefits of potential reward are building confidence among students. In this case the confidence is product of appreciation which is brought through the reward itself. When students have confidence, they are going to practice more in learning English. In this case, students have no worry to produce the mistakes in learning. Because, the teacher encourages them to explore the learning activity by providing reinforcement. The third benefit of potential reward is the target learning easily achieved. When there is student given a reward, the others will recognize what they should do to get that reward. Therefore it can encourage the students to achieve the goal of learning.

\section{ACKNOWLEDGMENT}

This research was supported by the Research Fund provided by Directorate of Research and Community Service, Directorate General for Research and Development, Ministry of Research, Technology and Higher Education. In accordance with the Research Contract for Fiscal Year 2019. The research scheme was "Penelitian Dosen Pemula". 


\section{REFERENCES}

Creswell, J. W. (2009). Research Design Qualitative, Quantitative, and Mixed Methods Approaches. Los Angeles : SAGE.

Dörnyei, Z. (2001). Teaching and Researching Motivation. Longman: Pearson Education Limited.

Edward, A. \& Knight, P. (2001). Effective Early Years Education. Buckingham: Open University Press.

Gardon, T. (2007). Teaching Young Children a Second Language. London: Praeger.

Gebhard, J.G., \& Oprandy, R. (1999). Language Teaching Awareness: A Guide to Exploring Beliefs and Practices. New York: Cambridge.

Halliwell, S. (1992). Teaching English in the Primary Classroom. Harlow: Longman.

Johnstone, R. (2009). An early start: What are the key conditions for generalized success? In J. Enever, J. Moon, and U. Raman (Eds.), Young Learner English Language Policy and Implementation: International perspectives (pp. 31-41). Reading, UK: Garnet Publishing.

Kail, R. V. (2012). Children and Their Development. Boston: Pearson.

Khaliq, A. ,Douna, M. S. R. \& Ahsan, M. (2016). Role of Reinforcement or Punishment in Learning English Language: A Study at Secondary Level in Southern Punjab Pakistan. International Journal of Business and Social Science. ISSN 2219-1933 (Print), 2219-6021 (Online). Vol. 7, No. 8; August 2016. www.ijbssnet.com.

Langa, C. (2014). Rewards and Punishments Role in teacher-Student Relationship from the Mentor's Perspective. ActaDidacticaNapocensia, ISSN 20651430. Volume 7, Number 4, 2014.

Lightbown, P. M., \&Spada, N. (2007). How Languages are Learned. Oxford: Oxford University Press.

Loi, D. P.,\&Uyen, N. T. L. (2016). Motivating EFL Classroom Participation by Rewarding at a Language Center in Ho Chi Minh City, Vietnam. Journal of Applied Linguistics and Language Research.ISSN: 2376-760X. Volume 3, Issue 5, 2016, pp. 177-189.

MacDonell, C. (2007). Project-based Inquiry Units for Young Children. Ohio: Linworth Publishing, Inc. 
WEJ, Vol 3 No 2 September 2019

McKay, P. (2006). Assessing Young Language Learners. Cambridge: Cambridge University Press.

Paradis, M. (2004). A Neurolinguistic Theory of Bilingualism. Amsterdam: John Benjamins.

Partin, R. L. (2009). The Classroom Teacher's Survival Guide. San Fransisco: Jossey-Bass.

Paul, D. (2003). Teaching English to Children in Asia. Hongkong: Pearson Education Asia Limited.

Pinter, A. (2011). Children Learning Second Languages. London: Palgrave Macmillan.

Puskas, A. (2016). The Challenges and Practices of Teaching Young Learners. Komarno : KEGA. 